\title{
Genecology and Seed Zones for Indian Ricegrass Collected in the Southwestern United States
}

\author{
R. C. Johnson, ${ }^{1}$ M. J. Cashman, ${ }^{2}$ and K. Vance-Borland ${ }^{3}$ \\ Authors are ${ }^{1}$ Research Agronomist and ${ }^{2}$ Biologist, USDA-ARS Plant Germplasm and Testing Unit, Pullman, WA 99164, USA; and ${ }^{3}$ Reseach Associate, \\ The Conservation Planning Institute, Corvallis, OR 97330, USA.
}

\begin{abstract}
Indian ricegrass (Achnatherum hymenoides [Roemer \& J.A. Schultes] Barkworth) is a widely distributed, highly desirable native species in desert ecosystems in the western United States. Yet there are no studies linking genetic variation in Indian ricegrass with climate across major areas of its natural distribution. In this study, seeds from 106 collection locations from the southwestern United States were established in common gardens and four phenological traits (Phen; such as blooming date), six production traits (Pro; such as dry weight), and eight morphology traits (Morph; such as leaf dimensions) were measured in 2007 and 2008. Analyses of variance revealed that all basic garden traits differed among source locations $(P<0.01)$, indicating widespread genetic variation. Within Phen, Pro, and Morph categories, canonical correlation was completed between basic garden traits and source location temperature and precipitation. This resulted in six significant $(P<0.01)$ canonical variates (Phen 1, Pro 1 and 2, and Morph 1, 2, and 3) representing each category of traits. Linear correlations $(r> \pm 0.25, P<0.01)$ consistently linked monthly temperature at collection locations with Phen 1, Pro 1, and Morph 1. For precipitation, however, correlations were more dependent on month, with the strongest correlations during the spring developmental period. Using regression models between traits and climate, a map with 12 seed zones was developed representing much of the southwestern United States. This generally distinguished genetic variation between cooler and warmer regions, usually separating more northern, higher elevation areas from more southern, lower elevation areas. The correspondence between climate and genetic variation suggested climate-driven differences in natural selection, likely leading to adaptation. The seed zone map is recommended to guide and broaden germplasm collection and utilization for Indian ricegrass restoration.
\end{abstract}

\section{Resumen}

Indian ricegrass (Achnatherum hymenoides [Roemer \& J.A. Schultes] Barkworth) presenta una amplia distribución, es una especie altamente deseable en los ecosistemas desérticos en el oeste de los estados Unidos. Sin embargo, aún no hay ningún estudio que relacione las variaciones genéticas de Indian ricegrass con el clima a través de las áreas de su distribución natural. En este estudio, semillas de 106 localidades del suroeste de Estados Unidos fueron colectadas y establecidas en jardines comunes y con cuatro características fenológicas (Phen; como día de floración), seis características productivas (Pro; como peso seco), y ocho características morfológicas (Morph; como dimensión de la hoja) fueron medidas en 2007 and 2008. Análisis de varianza revelaron que todas las características básicas fueron diferentes entre las localidades de origen $(P<0.01)$, indicando una amplia variación genética. Dentro de las categorías Phen, Pro, y Morph una correlación crónica fue completada entre las características básicas de jardín y fuente de origen, temperatura y precipitación. Esto resultó en seis variables crónicas significativas $(P<0.01 ;$ Phen 1, Pro 1 and 2, and Morph 1, 2, and 3) representando cada categoría de las características. Correlaciones lineales $(r> \pm 0.25, P<0.01)$ unieron consistentemente cada mes con la temperatura en cada colección y locación con Phen 1 , Pro 1 , and Morph 1. Para precipitación, sin embargo, las correlaciones fueron más dependientes de la variable mes, con las relaciones más fuerte en el periodo de desarrollo de primavera. Usando los modelos de regresión entre las características climáticas un mapa con 12 zonas de colección de semillas fue desarrollado representando la mayor parte del suroeste de Estados Unidos. Este mapa en general distinguió la variación genética entre las regiones más frías y las más cálidas, separando las localizadas más hacia el norte, con elevaciones más altas de las áreas mas hacia el sur con elevaciones más bajas. La correspondencia entre la variación genética y climática sugiere que el clima conduce a diferencias en selección natural, probablemente llevando a la adaptación. El mapa con las zonas de semillas se recomienda para guiar y ampliar la recolección de germoplasma y su utilización para la restauración de Indian ricegrass.

Key Words: Achnatherum hymenoides, common garden, genetic resources, germplasm, restoration, revegetation

\section{INTRODUCTION}

Research was funded in part by the Great Basin Native Plant Selection and Increase Project, Bureau of Land Management.

Correspondence: R. C. Johnson, USDA-ARS Plant Germplasm and Testing Unit, Box 646402, Washington State University, Pullman, WA 99614, USA. Email: rcjohnson@ wsu.edu

Manuscript received 6 September 2011; manuscript accepted 24 May 2012.
Land managers are increasingly using native plant genetic resources for restoration to maximize ecosystem diversity and function (Hufford and Mazer 2003; Jones and Monaco 2009; R. Johnson et al. 2010). Yet the long-term alternation of ecosystems make the prospect of returning them to their original state of complexity and diversity problematic (Jones 
and Monaco 2009), even after grazing is discontinued (Jeffries and Klopatek 1987). At the same time, using naturally occurring genetic variation for a given species is likely to add stability and complexity to the restoration process (Jump et al. 2008).

Even though there are exceptions (Leimu and Fischer 2008), reciprocal transplant studies with numerous species have shown that there often is a home-site advantage for locally derived germplasm sources (R. Johnson et al. 2010). Bleak et al. (1965), working in arid Nevada and Utah locations, observed that variation in native shrubs and grasses was often pronounced, and concluded that successful restoration, likely would depend of site-specific native plant germplasm. In addition to provenance, population diversity often is a critical component of successful restoration (Jump et al. 2008; Leimu and Fischer 2008; Bischoff et al. 2010). By using limited plant sources in restoration there is a heightened risk of genetic erosion over the landscape, which could limit the potential for future natural selection and adaptation (Endler 1986; Jump et al. 2008), especially with climate change.

If the choice of germplasm is to be broadened and more diverse for restoration then guidelines for geographic boundaries, that is, seed zones, must be established for a given area and species (St Clair et al. 2005; R. C. Johnson et al. 2010; R. Johnson et al. 2010). Seed zones used for restoration should originate from as wide a geographic area as possible to maximize efficient use of resources (R. C. Johnson et al. 2010) and dovetail with existing plant communities and ecosystems so that species diversity is not eroded by overly competitive genetic types (Hufford and Mazer 2003; Bischoff et al. 2010; R. C. Johnson et al. 2010). By linking genetic variation with climate, seed zones can be developed to guide restoration toward more locally or regionally adapted germplasm.

Reciprocal transplant studies (Rice and Knapp 2008), a direct test for local adaptation, is limited by the relatively small number of experimental test sites and seed sources that can be evaluated over a region of interest (Kawecki and Ebert 2004). Common garden experiments are a way to quantify genetically based phenotypic differences among a relatively large number of plant populations (Kawecki and Ebert 2004). Once an extensive collection for a given species is completed, longitude and latitude coordinates can be used to extract climatic variables for each source location (Daly et al. 2008). For genecology, plants from source locations are evaluated in common gardens and genetic traits determined though analyses of variance and correlation. Plant traits are simplified though multivariate statistics, and multilinear regression and geographic information systems (GIS) used to model and map the interaction between genetic variation and climate into seed zones (St Clair et al. 2005; R. C. Johnson et al. 2010).

In the western United States, Indian ricegrass (Achnatherum hymenoides [Roemer \& J.A. Schultes] Barkworth) is widely distributed and highly palatable for livestock and wildlife (Jones 1990). It is a key part of the desert ecosystem, promoting wildlife habitat and soil stabilization (USDA-NRCS 2000). Indian ricegrass is self-pollinating, yet is difficult to cross using traditional methods. As a result, cultivars to improve production and reduce seed dormancy have resulted from ecotype selection (Jones and Nielson 1989; USDA-NRCS 2000; Jones et al. 2010).
Although diversity among Indian ricegrass was attributed to natural selection more than $50 \mathrm{yr}$ ago (Bohmont and Lang 1957), genecology studies on Indian ricegrass have not been completed. The USDA maintains a collection of Indian ricegrass through the National Plant Germplasm System and the Western Regional Plant Introduction Station, Pullman, Washington, and the majority of these were collected across the southwestern United States. The objectives of this research were to 1) assess genetic diversity of Indian ricegrass collected in southwestern United States using common gardens, 2) determine if and to what extent plant trait variation was linked to source location climatic variables, and 3) visualize the interaction between genetic diversity and climate though multilinear regression modeling and GIS mapping to provide guidance for selecting genetic resources for restoration.

\section{METHODS}

\section{Germplasm and Garden Establishment}

Seeds from the USDA Indian ricegrass collection in 2006 were drawn from the Western Regional Plant Introduction Station in Pullman, Washington. The seeds were germinated as described by Jones and Nielson (1992) with minor modifications. Mechanical scarification was accomplished using compressed air at $500 \mathrm{kPa}$ to spin seeds within steel cylinder lined with medium grit sand paper for $1 \mathrm{~min}$. After scarification, at least 100 seeds from each source location were placed on saturated vermiculite within germination boxes measuring $14 \times 13 \mathrm{~cm}$ and $3.5 \mathrm{~cm}$ deep. The seeds in boxes were stratified for $8 \mathrm{wk}$ at $4^{\circ} \mathrm{C}$ beginning on 1 March 2006. The boxes were then removed and the seedlings transplanted into 10-cm-tall cells (Rannoch Rootrainers Ronaash Ltd., Scotland) each holding $100 \mathrm{~cm}^{3}$ of planting media. The planting media was comprised of three parts Sunshine \#5 plug mix (SunGro Horticulture, Bellevue, WA) and one part sand. Individual seedlings within each cell were placed in flats and moved to a greenhouse.

For southwestern collections, there were 109 source locations with adequate germination and with field-acquired latitude-longitude (56 locations) or latitude-longitude derived from collection descriptions using Google Earth (53 locations). Seedlings from three of the 109 collection locations did not produce adequate plants, leaving a total of 106 study locations.

Seedlings were randomized and maintained under greenhouse or lath house conditions until spring 2007. Plants were transported to the Central Ferry Research Farm (lat $46^{\circ} 40^{\prime} 18^{\prime \prime} \mathrm{N}$, long $\left.117^{\circ} 45^{\prime} 21^{\prime \prime} \mathrm{W}\right)$, Central Ferry, Washington, maintained in a lath-house for $2 \mathrm{wk}$, and transplanted on 5 April 2007 into moist soil.

The Central Ferry Research Farm is located along the Snake River canyon at an elevation of $200 \mathrm{~m}$ above sea level. Average climate data from 1971 to 2000 (Daly et al. 2008) showed precipitation at the farm averaged $332 \mathrm{~mm}$ and annual temperature $11.3^{\circ} \mathrm{C}$. For the 106 seed collection locations the corresponding precipitation and temperature averages were $294 \mathrm{~mm}$ (ranging from $136 \mathrm{~mm}$ to $633 \mathrm{~mm}$ ) and $10.0^{\circ} \mathrm{C}$ (ranging from $2.1^{\circ} \mathrm{C}$ to $17.0^{\circ} \mathrm{C}$ ).

Two common garden environments were established, one designated for supplemental irrigation and one without irrigation. The purpose of the irrigated garden was to assess 
potential genotype by environment interactions associated with differences in available water before blooming, potentially providing additional genetic traits for multilinear regression modeling.

For the irrigated garden, each supplemental irrigation was applied with overhead sprinklers for $2 \mathrm{~h}$, resulting in about 20 $\mathrm{mm}$ of applied water before blooming. In 2007, the establishment year, there were three irrigations; one each in mid-May, early June, and mid-June. For 2007, the sum of precipitation $(339 \mathrm{~mm})$ and irrigation $(60 \mathrm{~mm})$ was $399 \mathrm{~mm}$. In 2008, plant development was much earlier than in 2007 , so only a midMay irrigation was prescribed before blooming, resulting in a precipitation $(333 \mathrm{~mm})$ plus irrigation $(20 \mathrm{~mm})$, totaling 353 $\mathrm{mm}$.

Each garden was established in randomized complete blocks with five replications consisting of one plant per plot. The gardens were separated by about $75 \mathrm{~m}$; fertilizer was not applied to either garden. Each plant was spaced $0.6 \mathrm{~m}$ apart in rows on 2-m centers.

\section{Data Collection and Statistical Analysis}

Data were collected for each of the plant traits described in Table 1. Analyses of variance was completed within each year for each trait with PROC GLM in SAS/STAT software version 9.2 (SAS Institute, Cary, NC, USA). The variance was partitioned into environment (irrigated or dryland), blocks within environment, collection location, blocks within location, and the location by environment interaction. The block within environment variation was used as the error term for testing the difference between irrigation environments, the block within location variance as the error term for testing location differences, and the residual variance as the error term for testing the location by environment interaction.

Canonical correlation was used to relate common garden plant traits with climate variables at collection locations similar to St Clair et al. (2005). Because interpreting canonical variates can be problematic (Manly 1986), we placed the garden traits into phenology, production, and morphology categories so their meaning was defined a priori.

Prior to canonical correlation, significant garden traits were averaged or reduced as follows. If the source location by irrigation environment interaction was not significant $(P>0.01)$, means were averaged over environments. This averaging also was done in the presence of an interaction if the linear correlation between the environments was positive and significant $(P<0.01)$, indicating an interaction of magnitude and not direction. Within years, plant traits were considered redundant if the linear correlation coefficient between traits within phenology, production, and morphology categories was $r \geq 0.80$. In those cases the trait with the highest $\mathrm{F}$ value for collection locations was retained.

Canonical correlation (PROC CANCORR in SAS/STAT version 9.2, SAS Institute) was completed on each category of traits (Table 1) in relation to monthly and annual precipitation and temperature from source locations. Climate data were 30-yr averages (1971-2000) derived from Climate

Table 1. Analyses of variance summary of plant traits for Indian ricegrass collected in southwestern US locations (Loc) grown in dryland and irrigated common garden environments (Env) at Central Ferry, Washington, in 2007 and 2008 ( $n=106)$.

\begin{tabular}{|c|c|c|c|c|c|c|c|c|c|c|}
\hline \multirow[b]{2}{*}{ Plant factors } & \multicolumn{5}{|c|}{2007} & \multicolumn{5}{|c|}{2008} \\
\hline & Trait Mean $^{1}$ & Range (SD) & Env $(E)^{2}$ & $\operatorname{Loc}(\mathrm{L})$ & $E \times L$ & Trait Mean $^{2}$ & Range (SD) & Env $(E)^{1}$ & Loc (L) & $E \times L$ \\
\hline Phenology & \multicolumn{7}{|c|}{-----------P values---------- } & \multicolumn{3}{|c|}{---------- $P$ values----------- } \\
\hline Panicle emergence, ${ }^{3}$ day of year & $191.3^{3}$ & $38.8(13.0)$ & 0.009 & $<0.001$ & 0.823 & 148.1 & $10.5(2.32)$ & 0.714 & $<0.001$ & 0.209 \\
\hline First bloom, day of year & 179.7 & $34.0(11.7)$ & 0.012 & $<0.001$ & 0.057 & 138.8 & $11.7(2.93)$ & 0.501 & $<0.001$ & 0.872 \\
\hline Maturity, ${ }^{3}$ day of year & 205.1 & 45.5 (12.2) & 0.001 & $<0.001$ & 0.129 & 166.4 & $6.3(1.48)$ & 0.001 & $<0.001$ & $<0.001$ \\
\hline Blooming to maturity, days & 25.4 & $47.0(12.6)$ & 0.629 & 0.007 & 0.761 & 27.6 & $9.6(2.91)$ & 0.022 & $<0.001$ & 0.189 \\
\hline \multicolumn{11}{|l|}{ Production } \\
\hline Leaf abundance rating, 1 (low) to 9 (high) & 4.81 & $4.71(1.06)$ & 0.037 & $<0.001$ & 0.017 & 3.75 & $3.63(1.19)$ & 0.024 & $<0.001$ & 0.668 \\
\hline Seeds per lead panicle & 48.0 & $87.7(20.1)$ & 0.096 & $<0.001$ & 0.454 & 43.6 & $67.1(17.8)$ & 0.270 & $<0.001$ & 0.704 \\
\hline Panicle number per plant & 13.2 & $39.9(10.5)$ & 0.019 & $<0.001$ & 0.332 & 105.8 & $198(64.3)$ & 0.283 & $<0.001$ & 0.756 \\
\hline Dry weight, g & 22.2 & $73.3(19.2)$ & 0.027 & $<0.001$ & 0.180 & 46.0 & $50.8(36.0)$ & 0.706 & $<0.001$ & 0.523 \\
\hline Crown diameter area, (length $\times$ width)/2 & 25.7 & $60.1(14.9)$ & 0.007 & $<0.001$ & 0.154 & 34.3 & $56.5(17.3)$ & 0.913 & $<0.001$ & 0.635 \\
\hline Regrowth weight, g & 3.6 & $12.5(2.46)$ & 0.532 & $<0.001$ & 0.416 & 11.05 & $43.5(10.4)$ & 0.037 & $<0.001$ & 0.150 \\
\hline \multicolumn{11}{|l|}{ Morphology } \\
\hline Plant habit, rated 1 (prostrate) to 9 (upright) & 5.54 & $4.87(1.16)$ & 0.181 & $<0.001$ & 0.409 & 6.02 & $6.20(1.27)$ & 0.177 & $<0.001$ & 0.783 \\
\hline Leaf roll, rated 1 (flat) to 9 (cylindrical) & 4.54 & $6.50(1.58)$ & 0.098 & $<0.001$ & 0.011 & 6.85 & $5.68(1.35)$ & 0.634 & $<0.001$ & 0.873 \\
\hline Leaf texture, rated 1 (coarse) to 9 (fine) & 5.24 & $5.50(1.32)$ & 0.041 & $<0.001$ & 0.376 & 5.64 & $3.63(1.19)$ & 0.989 & $<0.001$ & 0.573 \\
\hline Flag leaf width, $\mathrm{cm}$ & 0.184 & $0.19(0.077)$ & 0.056 & $<0.001$ & 0.514 & 0.155 & $0.144(0.056)$ & 0.894 & $<0.001$ & 0.338 \\
\hline Flag leaf length, $\mathrm{cm}$ & 14.6 & $17.9(4.58)$ & 0.939 & $<0.001$ & 0.878 & 13.1 & $14.2(3.82)$ & 0.416 & $<0.001$ & 0.299 \\
\hline Leaf length $\times$ leaf width, $\mathrm{cm}^{2}$ & 2.83 & $6.21(1.94)$ & 0.347 & $<0.001$ & 0.916 & 2.13 & $4.28(1.22)$ & 0.731 & $<0.001$ & 0.519 \\
\hline Culm length, ${ }^{3} \mathrm{~cm}$ & 25.1 & $36.3(5.3)$ & 0.306 & $<0.001$ & 0.126 & 27.0 & $28.2(6.29)$ & 0.858 & $<0.001$ & 0.096 \\
\hline Panicle length, $\mathrm{cm}$ & 14.9 & $14.1(4.0)$ & 0.315 & $<0.001$ & 0.634 & 12.9 & $12.0(3.07)$ & 0.156 & $<0.001$ & 0.235 \\
\hline
\end{tabular}

${ }^{1}$ Trait means in bold indicate nonredundant plant traits used for canonical correlation.

${ }^{2}$ Dryland or irrigated environments.

${ }^{3}$ Panicle emergence was complete emergence of the first inflorescence (usually after first bloom), maturity was when seed shattering was observed in half the inflorescences, culm length was measured from the plant base to the base of the panicle on a lead culm. 
WNA $^{1}$ using PRISM spatial models ${ }^{2}$ (Daly et al. 2008) at a grid resolution of 30 -arcsec $(\approx 800 \mathrm{~m})$. Significant phenology, production, and morphological canonical variates $(P<0.01)$ were identified and used in regression modeling as described below. In addition, to facilitate modeling seed zones, those variates were used in an additional canonical correlation analysis to derive conflated canonical variates defined as cancorr extracts.

Multilinear regression modeling, completed with the canonical variates as the dependent variable, were regressed on temperature and precipitation variables at source locations using SAS PROC REG in SAS/STAT version 9.2 (SAS Institute). The objective was to find models with the highest predictive value, combined with the fewest number of model parameters, to minimize over parameterization (Draper and Smith 1998). Within PROC REG, the maximum $R^{2}$ improvement (MAXR) option was used to maximize predictive power and the Mallows $C_{p}$ statistic (Mallows 1973) to minimize over parameterization. For a given canonical variate, monthly and annual temperature and precipitation variables for locations were regressed so that the $R^{2}$ was maximized, and with the $\mathrm{C}_{p}$ statistic calculated progressively. The method starts by developing a model with one climatic variable with maximized $R^{2}$, then two, and so forth for all climatic variables. The model selected was the maximum $R^{2}$ model when the $C_{p}$ statistic, which initially declines with increasing variables, starts to increase (Mallows 1973). That is the point when adding variables only marginally improves the $R^{2}$ and the model.

\section{Mapping and Seed Zone Development}

Mapping of canonical variates predicted from multivariate regression models was completed using the grid algebra function (raster calculator) of the ArcGIS 9.3 Spatial Analyst extension (ESRI, Redlands, CA). Each environmental variable was multiplied by its respective regression coefficient and the results summed. Map boundaries were limited to Omernik level III ecoregions (Omernik 1987) where plant material was collected. Mapped areas also were confined to the observed range of the canonical variate scores for the 106 collection locations. Similar to Rehfeldt (1986), a mapping contour interval corresponding to two times the $95 \%$ confidence interval at the model mean was calculated using the regression model error term. Seed zones delineating areas of similar plant trait variation were created by classifying rasters for canonical variates into high, medium, or low categories over the range of the canonical variate scores, and then overlaying the resulting rasters, similar to St Clair et al. (2005).

\section{RESULTS}

\section{Analyses of Variance}

Source locations within years differed for all garden plant traits, indicating genetic variation among Indian ricegrass across the southwestern United States (Table 1). The irrigation treatment had a significant $(P<0.01)$ effect on numerous plant traits, especially in 2007, when irrigation advanced panicle

\footnotetext{
1http://www.genetics.forestry.ubc.ca/cfcg/ClimateWNA/ClimateWNA.html

${ }^{2}$ http://www.ocs.orst.edu/prism/
}

emergence, maturity, and blooming by $11-13 \mathrm{~d}$, and resulted in larger crown diameter, $68 \%$ more dry weight, and $62 \%$ more panicles (data not shown). In 2008, maturity and days from blooming to maturity were little affected by irrigation, averaging $2 \mathrm{~d}$ later in the dryland than irrigated garden.

Overall, development was much earlier in 2008 than in 2007, the year of plant establishment. For example, average blooming was 18 May in 2008 and 29 June in 2007 (Table 1). This meant that in 2008 much more plant development occurred in cooler, moister spring conditions compared to 2007, diminishing the effects of irrigation in 2008 (Table 1). In 2008 the expected increase in production, owing to growth after the establishment year, was observed with many more panicles per plant and much higher dry weight and regrowth (Table 1).

Even with the irrigation effects, the only significant $(P<0.01)$ interaction between the irrigation environment and source location was maturity in 2008 , although interactions for leaf roll in 2007 and leaf abundance 2007 were relatively strong (Table 1). In those cases correlations between irrigation environments were positive and significant for maturity 2008 $(r=0.39, P<0.0001)$ for leaf roll $2007(r=0.40, P<0.0001)$, and for leaf abundance $2007(r=0.22, P<0.023)$, indicating interactions of magnitude, not direction. As a result, traits for irrigated and nonirrigated gardens within years were averaged over locations prior to canonical correlation analysis. Linear correlation analyses to reduce redundant traits for canonical correlation resulted in a final set of five basic garden traits for phenology, eight for production, and 14 for morphology (Table $1)$.

\section{Canonical Correlation and Geographic Mapping}

Canonical correlation (Table 2) revealed one significant canonical variate for phenology (Phen 1), two for production (Pro 1 and 2) and three for morphology (Morph 1, 2, and 3). Nearly half of the variation in the original phenology traits was explained by Phen 1 , a total of $55 \%$ for Pro 1 and 2, and a total of $54 \%$ for Morph 1, 2, and 3 (Table 2).

Significant linear correlations between phenology-based garden traits and temperature were frequent and positive (Table 3), showing the trend in common gardens toward later panicle emergence, later maturity, and a longer maturation period for higher-temperature locations. For precipitation, correlations with garden traits were negative, showing a trend toward later development in common gardens for locations with lower precipitation (Table 3). Although less frequent, correlation was often observed for production and morphological traits.

All basic garden traits associated with phenology correlated with Phen 1, most with Pro 1 and Pro 2, and fewer with Morph 1, 2, and 3 (Table 3). However, for all but four traits in 2007 (leaf roll, leaf texture, flag leaf width, and panicle length), correlation with basic garden traits and Morph 1, 2, or 3 were significant for at least one of the three (Table 3).

There were contrasts in correlation slope between 2007 and 2008 for panicle emergence and Phen 1, and for leaf abundance and Pro 1 (Table 3). The much later development in the establishment year (2007) than the second year (2008) of the study (Table 1) exposed plants to warmer, dryer conditions and 
Table 2. Summary of significant canonical variates $(P<0.01)$ resulting from canonical correlation between common garden traits for phenology (Phen), production (Pro), and morphology (Morph) and annual and monthly temperature and precipitation for Indian ricegrass at collection locations from the southwestern United States $(n=106)$. Also provided is a summary of statistics for regression models between each canonical variate and temperature and precipitation data.

\begin{tabular}{|c|c|c|c|c|c|c|}
\hline & \multicolumn{6}{|c|}{ Canonical variates } \\
\hline & Phen 1 & Pro 1 & Pro 2 & Morph 1 & Morph 2 & Morph 3 \\
\hline Variation explained, \% & 49 & 35 & 20 & 25 & 18 & 11 \\
\hline Canonical correlation & 0.75 & 0.78 & 0.69 & 0.83 & 0.79 & 0.71 \\
\hline Canonical $F$ value & 1.51 & 1.62 & 1.33 & 1.66 & 1.46 & 1.29 \\
\hline Canonical $P$ value & 0.002 & $<0.001$ & 0.010 & $<0.001$ & $<0.001$ & 0.004 \\
\hline Correlation, ave. temp. ${ }^{1}$ & $0.48^{\star *}$ & $-0.48^{\star *}$ & $0.21^{*}$ & $0.31^{* *}$ & $0.25^{\star \star}$ & $0.22^{*}$ \\
\hline Correlation, ave. precip. ${ }^{1}$ & $-0.33^{\star *}$ & $0.33^{\star \star}$ & $-0.21^{\star}$ & $-0.24^{\star}$ & $-0.26^{\star *}$ & $-0.38^{\star \star}$ \\
\hline Regression variable number ${ }^{2}$ & 10 & 10 & 10 & 12 & 14 & 7 \\
\hline Regression $F$ value & 10.22 & 13.09 & 7.45 & 15.34 & 9.69 & 10.01 \\
\hline Regression $P$ value & $<0.001$ & $<0.001$ & $<0.001$ & $<0.001$ & $<0.001$ & $<0.001$ \\
\hline Regression $R^{2}$ value & 0.52 & 0.46 & 0.44 & 0.66 & 0.46 & 0.42 \\
\hline
\end{tabular}

${ }^{1}$ Linear correlation significant at $* P<0.05$ and $* * P<0.01$.

${ }^{2}$ Regression models were developed for each canonical variate as the dependent variable, and monthly and annual temperature as the independent variable.

Table 3. Linear correlation coefficients between plant traits and annual average temperature, annual average precipitation, and significant canonical variates $(P<0.01)$ for phenology (Phen 1), production (Pro 1 and 2), and morphology (Morph 1, 2, and 3) for Indian ricegrass grown in common gardens and collected from the southwestern United States $(n=106)$.

\begin{tabular}{|c|c|c|c|c|c|}
\hline \multirow[b]{2}{*}{ Garden traits } & \multicolumn{5}{|c|}{ Correlation coefficients $^{1}$} \\
\hline & Ave. temp. & Ann. precip. & Phen 1 & & \\
\hline \multicolumn{6}{|l|}{ Phenology } \\
\hline Panicle emergence 2007 & -0.14 & 0.06 & $-0.26^{\star \star}$ & & \\
\hline Panicle emergence 2008 & $0.33^{\star \star}$ & $-0.27^{\star \star *}$ & $0.82^{\star \star}$ & & \\
\hline First bloom 2008 & $0.21^{*}$ & -0.16 & $0.47^{\star \star}$ & & \\
\hline Maturity 2008 & $0.41^{\star *}$ & $-0.24^{\star \star}$ & $0.73^{\star \star}$ & & \\
\hline Blooming to maturity 2007 & $0.31^{* *}$ & $-0.22^{*}$ & $0.50^{\star \star *}$ & & \\
\hline Production & Ave. temp. & Ann. precip. & Pro 1 & Pro 2 & \\
\hline Leaf abundance 2007 & $-0.30^{\star \star}$ & 0.09 & $0.36^{\star *}$ & 0.13 & \\
\hline Leaf abundance 2008 & $0.21 *$ & -0.13 & $-0.45^{\star \star}$ & -0.05 & \\
\hline Seeds per lead panicle 2007 & 0.03 & 0.15 & $0.30^{\star \star}$ & $0.27^{\star \star}$ & \\
\hline Seeds per lead panicle 2008 & -0.17 & $0.29 * \star$ & $0.59^{* *}$ & -0.12 & \\
\hline Panicles per plant 2007 & $0.28^{* *}$ & -0.18 & $-0.63^{\star \star}$ & $0.21^{\star}$ & \\
\hline Panicle per plant 2008 & -0.07 & 0.17 & 0.04 & $-0.25^{\star \star}$ & \\
\hline Dry weight 2007 & $0.32^{\star \star}$ & -0.11 & $-0.50 * *$ & $0.23^{\star}$ & \\
\hline Dry weight 2008 & 0.12 & 0.05 & 0.01 & $0.30^{* *}$ & \\
\hline Morphology & Ave. temp. & Ann. precip. & Morph 1 & Morph 2 & Morph 3 \\
\hline Plant habit 2007 & $0.23^{*}$ & -0.05 & $0.24^{*}$ & $0.26^{\star *}$ & 0.18 \\
\hline Plant habit 2008 & $0.36^{\star \star}$ & $-0.36^{\star \star}$ & 0.17 & $0.38^{* \star}$ & $0.62^{\text {** }}$ \\
\hline Leaf roll 2007 & $-0.28 * *$ & 0.03 & 0.17 & 0.10 & -0.11 \\
\hline Leaf roll 2008 & 0.06 & -0.13 & $0.31^{\star \star}$ & $0.67^{\star *}$ & -0.13 \\
\hline Leaf texture 2007 & $-0.32^{\star \star}$ & 0.07 & -0.12 & -0.07 & 0.17 \\
\hline Leaf texture 2008 & -0.07 & -0.02 & $0.42^{\star \star}$ & 0.16 & 0.00 \\
\hline Flag leaf length 2007 & $0.24^{*}$ & -0.02 & $0.19^{*}$ & $0.33^{\star *}$ & $-0.42^{\star *}$ \\
\hline Flag leaf length 2008 & 0.20 & 0.06 & -0.02 & 0.14 & $-0.41^{\star *}$ \\
\hline Flag leaf width 2007 & $0.30^{\star \star}$ & -0.06 & 0.14 & -0.12 & 0.00 \\
\hline Flag leaf width 2008 & 0.08 & -0.04 & 0.01 & $-0.56^{\star \star}$ & 0.15 \\
\hline Culm length 2007 & -0.14 & $0.30 * *$ & -0.12 & -0.18 & -0.50 ** \\
\hline Culm length 2008 & -0.05 & $0.19^{*}$ & $-0.43^{\star \star}$ & -0.08 & -0.17 \\
\hline Panicle length 2007 & 0.06 & 0.02 & -0.09 & -0.03 & -0.18 \\
\hline Panicle length 2008 & -0.11 & $0.22 *$ & $-0.32^{\star *}$ & $-0.32^{\star *}$ & $-0.35^{\star \star}$ \\
\hline
\end{tabular}

${ }^{1}$ Linear correlation significant at $* P<0.05$ and $* * P<0.01$. 
affected growth and development. Nevertheless, data from both years revealed significant, useful genetic traits (Table 1) that correlated with location temperature and precipitation (Tables 2 and 3).

Although trending lower in the winter, linear correlation between monthly average temperature and Phen 1 and Pro 1 (Fig. 1) were all highly significant. The same general pattern was observed for Morph 1, but with correlations somewhat weaker (Fig. 1). For precipitation, Phen 1, Pro 1, and Morph 1 were most strongly correlated with precipitation in the spring months (Fig. 1), corresponding to the most active period of growth and development for Indian ricegrass (Pearson 1979). A similar but weaker pattern was observed for Morph 2. Yet for Pro 2, and to a greater extent Morph 3, the strongest correlation with precipitation was July through October (Fig. 1 ), which includes the southwestern US monsoon precipitation period.

Multilinear regression of Phen 1, Pro 1 and 2, and Morph 1, 2 , and 3 with source location temperature and precipitation

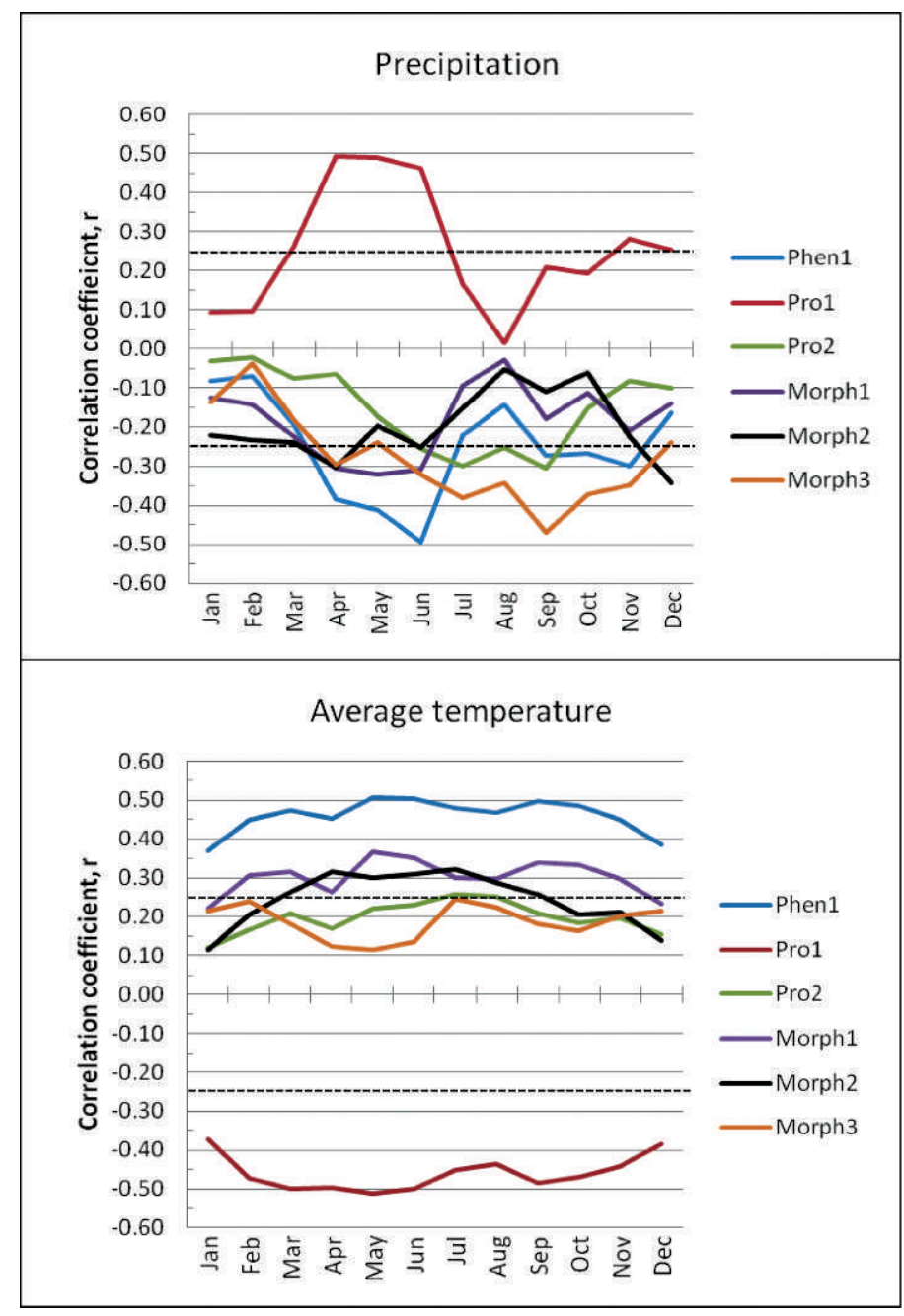

Figure 1. Linear correlation coefficients between monthly temperature and precipitation and significant $(P<0.01)$ canonical variates for phenology (Phen 1), production (Pro 1 and 2), and morphology (Morph 1, 2, and 3) for Indian ricegrass grown in common gardens from locations in the southwestern United States $(n=106)$. The dashed line represents the $P=0.01$ significance level. were highly significant, with $R^{2}$ values ranging between 0.66 and 0.42 (Table 2). Thus, the regression models successfully linked climate the canonical variates.

Maps for Phen 1 showed a pattern that divided generally between higher temperature areas in the south and lower temperature areas in the north (Fig. 2). For example, the predominantly blue and green hues of the warm Mojave Basin and Range and much of the Arizona/New Mexico plateau contrasted to the yellow and brown hues of the cooler Central Basin and Range and Wyoming Basin (Fig. 2). The same general north-south pattern was observed for Pro 1 and Morph 1.

Pro 2, Morph 2, and Morph 3, displaying different dimensions of the data, showed a different pattern. For Pro 2 much of the ecoregion areas mapped to green and yellow hues associated with the middle range of the canonical variate scores (Fig. 2). Rather than a north-south bias, Morph 2 was similar in much of the western and eastern ecoregions compared to the Colorado Plateau, and the Arizona/New Mexico Plateau (Fig. 2). And for Morph 3, much of the western and northern ecoregions mapped to largely green hues, but with lower canonical variate scores, represented by yellow and orange hues, differentiating parts of the southwestern Tablelands and adjacent ecoregions.

\section{Seed Zone Development}

The six significant canonical variates (Table 2) represented too many traits to easily overlay and visualize in a single regional seed zone map. The minimum for six multilinear traits would be overlays of high and low scores of each, resulting in 36 seed zones. Such an array would be difficult to visually discriminate in maps and implement in practice. So an additional canonical correlation analysis using Phen 1, Pro 1 and 2, and Morph 1, 2, and 3 traits was completed, resulting in four significant canonical variates (cancorr extract traits) that together explained more than $91 \%$ of the total variation (Table 4 ).

Linear correlation coefficients between cancorr extract 1 and Phen 1, Pro 1, and Morph 1 (Table 4) showed the expected associations. Cancorr extract 2 was highly correlated with Morph 2, and cancorr extract 3 with Morph 3. Correlations of cancorr extracts 1, 2, and 3 were all significant for temperature and precipitation, but not for cancorr extract 4 (Table 4). As a result, seed zone development was based only on cancorr extracts 1, 2, and 3, which together explained $81 \%$ of the variation in the six original canonical variates.

For seed zones, the combined attributes of cancorr extracts 1,2 , and 3 were included by overlaying cancorr extracts based on the multilinear regression models (Table 5) resulting in 12 seed zones (Fig. 3). Cancorr extract 1 explained much more of the variation than cancorr extract 2 and 3 so it was more highly weighted in the mapping, with high, middle, and low sections, compared with only high and low sections for cancorr extract 2 and 3 (Fig. 3).

The seed zone-mapped area represented $1084476 \mathrm{~km}^{2}$ (Table 6). A total of $92 \%$ of the eight ecoregions studied were within the range of the cancorr extract scores and were thus mapped (Fig. 3). The largest seed zone was the light green M1L2H3 representing nearly $30 \%$ of the total mapped area; the smallest zone was the reddish brown L1H2L3 representing 


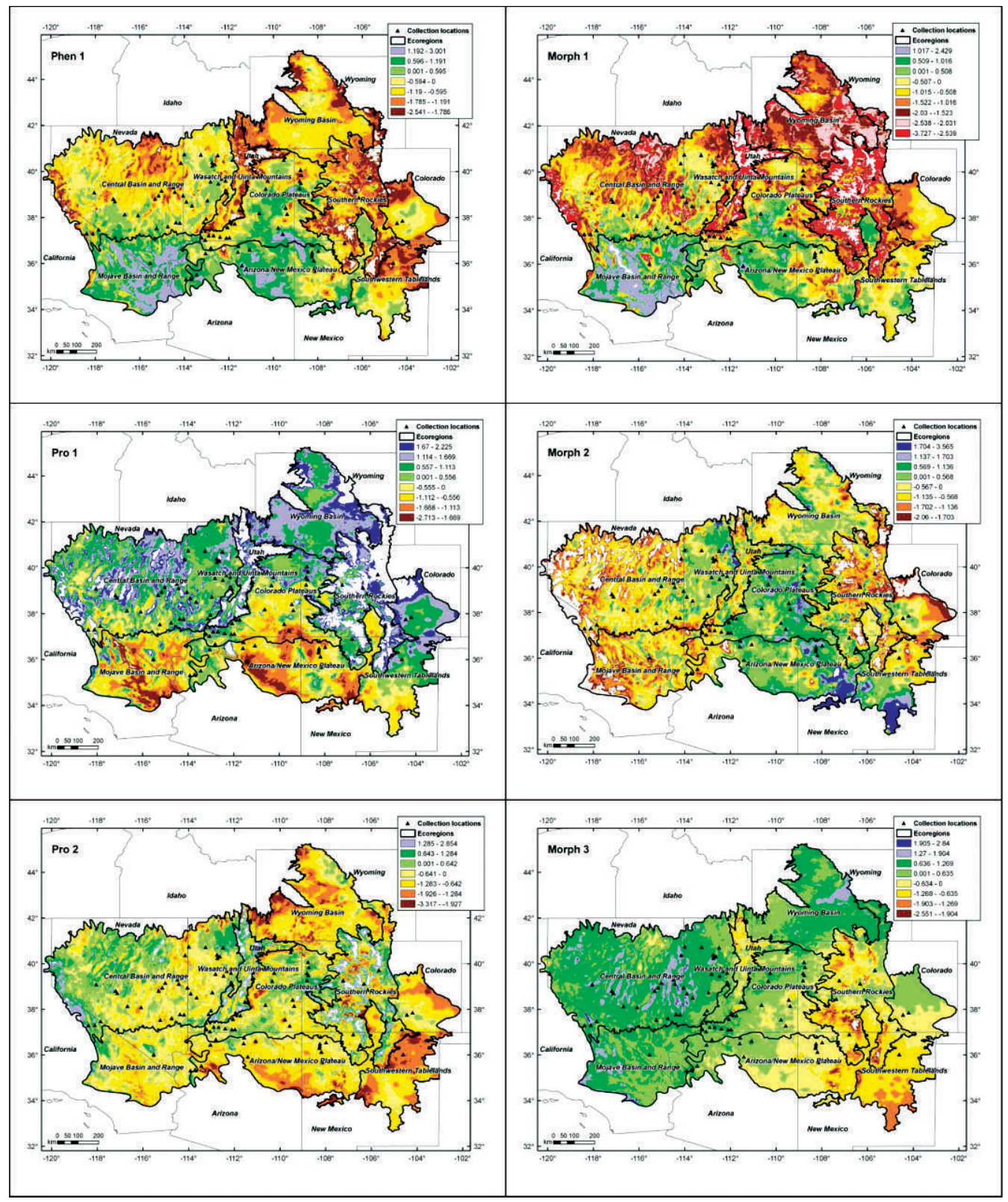

Figure 2. Maps based on regression models for significant $(P<0.01)$ canonical variates derived from Indian ricegrass plant traits grown in common gardens. Model predictions outside the range of the original canonical variate scores, shown in white, were not mapped. The contours were 2 times the 95\% confidence interval based on the regression model error.

just $1.4 \%$ (Fig. 3; Table 6). Regions outside the range of the cancorr extract scores usually corresponded to higher elevation in the Wasatch and Unita Mountains and the southern Rockies (Fig. 3).

The seed map showed the general north-south division observed in the maps of Phen 1, Pro 1, and Morph 1 (Fig. 2). However, additional detail was revealed, for example, in the dark brown area in the northeastern Central Basin and Range, associated with zone $\mathrm{L} 1 \mathrm{H} 2 \mathrm{H} 3$ and in the area along the border between the Colorado Plateau and the ArizonalNew Mexico plateau shown in the dark blue $\mathrm{H} 1 \mathrm{H} 2 \mathrm{H} 3$ (Fig. 3). This generally corresponded to the lower elevation, warmer areas in the Colorado River basin, including the San Juan and Little Colorado river tributaries. Most of the Mojave Basin and
Range and significant portions of the Arizona/New Mexico plateau mapped to the middle blue zone shown H1L2H3.

\section{DISCUSSION}

Although average location temperature showed a consistent association with the canonical variates (Fig. 1), other genecology studies have shown that maximum and minimum temperatures can vary in importance to plant traits. For oceanspray (Holodiscus discolor [Pursh] Maxim.), source location minimum temperatures were more consistently correlated over months with plant traits than maximum temperatures (Horning et al. 2008). In Douglas fir (Pseudotsuga menziesii [Mirb.] Franco var. menziesii) winter minimums were 
Table 4. Statistical summary of significant $(P<0.01)$ canonical variates (cancorr extracts) derived from canonical correlation of phenology (Phen 1), production (Pro 1 and 2), and morphology (Morph 1, 2, and 3) with annual and monthly temperature and precipitation for Indian ricegrass grown in common gardens and collected from the southwestern United States $(n=106)$.

\begin{tabular}{|c|c|c|c|c|}
\hline & $\begin{array}{l}\text { Cancorr } \\
\text { extract } 1\end{array}$ & $\begin{array}{l}\text { Cancorr } \\
\text { extract } 2\end{array}$ & $\begin{array}{l}\text { Cancorr } \\
\text { extract } 3\end{array}$ & $\begin{array}{l}\text { Cancorr } \\
\text { extract } 4\end{array}$ \\
\hline Variation explained, \% & 42.5 & 22.7 & 15.9 & 10.4 \\
\hline Canonical correlation & 0.87 & 0.80 & 0.74 & 0.66 \\
\hline$F$ value & 3.31 & 2.58 & 2.1 & 1.64 \\
\hline \multirow[t]{2}{*}{$P$ value } & $<0.001$ & $<0.001$ & $<0.001$ & 0.004 \\
\hline & \multicolumn{4}{|c|}{----- Linear correlation coefficients ${ }^{1}-$} \\
\hline Phen 1 & $0.74^{\star *}$ & $0.27^{\star *}$ & $0.19 *$ & 0.14 \\
\hline Pro 1 & $-0.73^{\star *}$ & $-0.45^{\star \star}$ & $0.19^{*}$ & 0.11 \\
\hline Pro 2 & -0.04 & $0.28^{* *}$ & $0.48 * *$ & $0.80^{* *}$ \\
\hline Morph 1 & $0.91^{* *}$ & -0.15 & 0.02 & 0.18 \\
\hline Morph 2 & 0.13 & $0.95^{\star *}$ & $-0.26^{\star \star}$ & -0.04 \\
\hline Morph 3 & 0.05 & 0.18 & $0.83^{\star *}$ & $-0.50^{\star \star}$ \\
\hline Source temperature & $0.43^{* *}$ & $0.29 * \star$ & $0.20 *$ & $0.03 \mathrm{~ns}$ \\
\hline Source precipitation & $-0.31^{\star *}$ & $-0.32^{\star *}$ & $-0.33^{\star \star}$ & $0.05 \mathrm{~ns}$ \\
\hline
\end{tabular}

${ }^{1}$ Linear correlation significant at ${ }^{*} P<0.05$ and ${ }^{* *} P<0.01$; ns indicates not significant.

most critical (St Clair et al. 2005). Yet in mountain brome (Bromus carinatus Hook. \& Arn.) location maximum temperatures appeared most strongly linked to plant traits (R. C. Johnson et al. 2010). For this study, correlations between monthly maximum and minimum temperature and Phen 1 , Pro 1 and 2, and Morph 1, 2, and 3 gave essentially the same result as for average temperature (Fig. 1). Average monthly temperatures also were highly correlated with both maximum and minimum temperatures $(r>0.94, P<0.0001)$. Thus, to simplify the canonical correlation and regression modeling, only average temperatures were used.

Because elevation is not technically a climate variable, it was not used in the canonical correlation or regression modeling, even though it was correlated with numerous basic garden traits. We felt that models excluding elevation might be more durable in an age of rapid climate change. Still, elevation correlated with average temperature $(r=-80, P<0.0001)$ and precipitation $(r=0.43, P<0.0001)$ as expected, showing it was to a large extent integrated within the analysis.

Because climate is a major factor in natural selection (Endler 1986; Kawecki and Ebert 2004), the observed interaction between plant traits and climate, mapped as seed zones, suggested that plant trait variation was to an important extent driven by natural selection, likely leading to differences in adaptation.

Ecoregions are based on a complex array of hierarchal factors, including geology, vegetation, climate, soils, land use, wildlife, water quality, and hydrology (Omernik 1987); they do not focus specifically on genetic and climate variation for a given species as our seed zone did for Indian ricegrass. Seed zones were only partially associated with ecoregions, or in the case of M1L2H3, widely spaced over ecoregions (Fig. 3); thus, ecoregions were not an adequate surrogate. That was also true for a genecology study of mountain Brome (R. C. Johnson et al. 2010). Given that seed zones should integrate genetic variation
Table 5. Model variables, coefficients, $P$ values, standardized coefficients, model fit $\left(R^{2}\right)$, and error mean square (MS) for multilinear regression of canonical correlation extracts 1, 2, and 3 with annual and monthly temperature and precipitation at Indian ricegrass grown in common gardens and collected from the southwestern United States $(n=106)$.

\begin{tabular}{|c|c|c|c|}
\hline Variable & $\begin{array}{l}\text { Regression } \\
\text { coefficient }\end{array}$ & $P>\mathrm{t}$ value & $\begin{array}{c}\text { Standardized } \\
\text { coefficient }\end{array}$ \\
\hline & \multicolumn{3}{|c|}{ 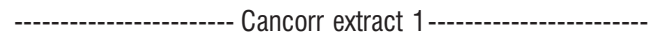 } \\
\hline Intercept & -4.72811 & 0.0017 & 0 \\
\hline Temp Feb & 0.44577 & 0.0286 & 1.37212 \\
\hline Temp Mar & -1.06891 & $<0.0001$ & -2.90601 \\
\hline Temp Apr & -1.19601 & $<0.0001$ & -3.18517 \\
\hline Temp Jun & -0.64844 & 0.0155 & -1.77989 \\
\hline Temp Jul & -1.8549 & $<0.0001$ & -5.26114 \\
\hline Temp Nov & -0.43385 & 0.0636 & -1.16125 \\
\hline Temp Dec & -2.48408 & $<0.0001$ & -6.92536 \\
\hline Temp Annual & 7.32567 & $<0.0001$ & 19.35435 \\
\hline Precip Oct & 0.04402 & 0.0008 & 0.4436 \\
\hline Precip Nov & -0.08252 & $<0.0001$ & -0.68275 \\
\hline$R^{2}$ & 0.72 & & \\
\hline \multirow[t]{2}{*}{ Error MS (df) } & \multicolumn{2}{|l|}{$0.31406(95)$} & \\
\hline & & orr extract 2 & \\
\hline Intercept & 1.5853 & 0.4321 & 0 \\
\hline Temp Mar & -0.38178 & 0.0491 & -1.03794 \\
\hline Temp Apr & 0.84294 & $<0.0001$ & 2.24488 \\
\hline Temp Jul & 1.63706 & $<0.0001$ & 4.64325 \\
\hline Temp Aug & -1.45339 & $<0.0001$ & -3.98168 \\
\hline Temp Oct & -1.17866 & $<0.0001$ & -2.96406 \\
\hline Temp Dec & 0.57923 & $<0.0001$ & 1.61484 \\
\hline Precip Mar & -0.08063 & 0.0008 & -0.98528 \\
\hline Precip Apr & 0.05691 & 0.0081 & 0.60988 \\
\hline Precip Jun & -0.11082 & $<0.0001$ & -1.01624 \\
\hline Precip Jul & -0.04475 & 0.0033 & -0.62118 \\
\hline Precip Sep & 0.05402 & 0.0114 & 0.49681 \\
\hline Precip Dec & -0.07156 & 0.003 & -0.55018 \\
\hline Precip Annual & 0.01458 & 0.0096 & 1.41363 \\
\hline$R^{2}$ & 0.59 & & \\
\hline Error MS (df) & \multicolumn{2}{|l|}{$0.46408(92)$} & \\
\hline Intercept & -5.93393 & 0.0001 & 0 \\
\hline Temp Mar & 0.20445 & 0.1581 & 0.5584 \\
\hline Temp Apr & -0.75549 & $<0.0001$ & -2.012 \\
\hline Temp Jul & 0.53961 & $<0.0001$ & 1.53051 \\
\hline Precip Jan & -0.05313 & 0.0079 & -0.5867 \\
\hline Precip Feb & 0.05267 & 0.0025 & 0.59735 \\
\hline Precip Oct & -0.04593 & 0.0001 & -0.46287 \\
\hline Precip Dec & 0.04811 & 0.0688 & 0.36986 \\
\hline$R^{2}$ & 0.44 & & \\
\hline Error MS (df) & $0.59583(98)$ & & \\
\hline
\end{tabular}

and climate, we recommend genecology studies be pursued for other key rangeland species and areas. Nevertheless, factors such as soils or biotic stresses can relate to adaptation and not correlate directly with climatic factors. In those cases local knowledge of land mangers is critical, especially for seed zones with wide geographic separation. 


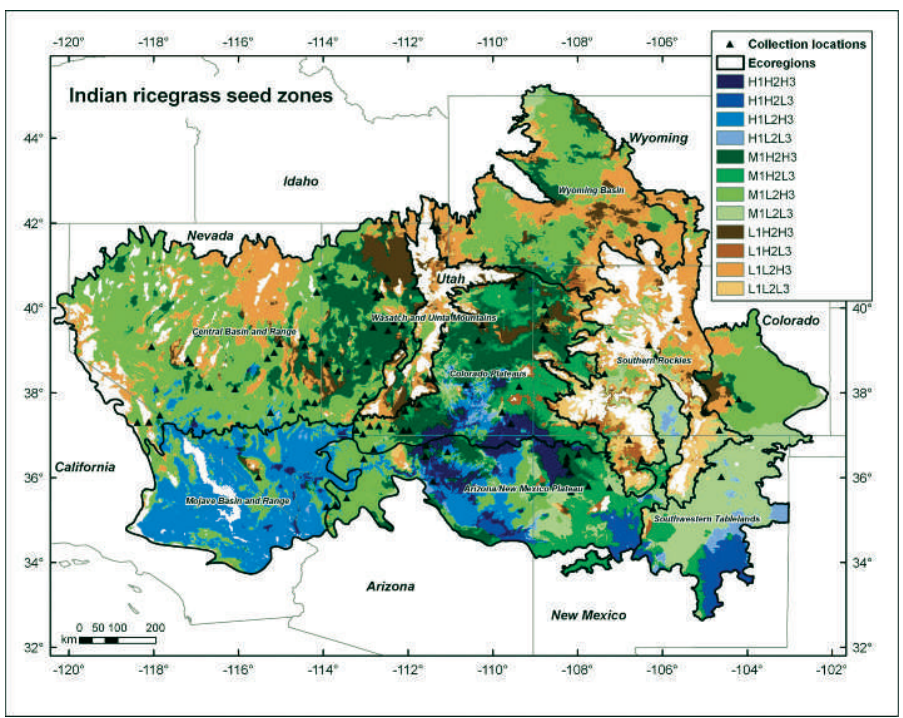

Figure. 3. Proposed seed zones for Indian ricegrass in the southwestern United States resulting from overlays of canonical variate scores (cancorr extracts) derived from phenology (Phen 1), production (Pro 1 and 2), and morphology (Morph 1, 2, and 3). Abbreviations H1, M1, and L1 refer to high, middle, and low ranges of cancorr extract 1 scores; $\mathrm{H} 2$ and $\mathrm{L} 2$, and $\mathrm{H} 3$ and L3, refer to high and low ranges of cancorr extracts 2 and 3 , respectively. Model predictions outside the range for the original canonical variate scores, shown in white, were not mapped.

We sought to develop seed zones as large as possible to promote efficient use of resources without unduly compromising the association of genetic diversity and climate, naturally resulting in some subjectively. The contour interval for mapping, twice the $95 \%$ confidence interval of the regression model error, resulted in relatively wide contour intervals and large seed zones.

Modification of seed zones should be ongoing, based on management considerations, experience, and additional research. Coalescence of relatively small areas within zones, or zones with smaller areas (Fig. 3; Table 6), can facilitate efficient management. Smaller or larger zones can be recommended by land managers in a certain areas or ecoregions, and these could be developed using the basic regression models and error terms provided (Table 5). Other factors such as microclimates, challenges of mined sites, invasive weeds, or other types of severe degradation could also affect the choice of germplasm for a given area.

Selection in Indian ricegrass germplasm has emphasized seed production potential, reduced seed dormancy, and less seed shattering (Jones 1990; USDA-NRCS 2000; Jones et al. 2010). This has the advantage of providing more agronomically suited germplasm, but does not ensure adaptation over diverse environments and ecosystems (R. Johnson et al. 2010). Wide adaptation might be possible in selected material, but other potential drawbacks include a loss of genetic diversity among populations and less favorable interactions with other plant and animal species (McAdoo et al. 1983; Hufford and Mazer 2003; Jump et al. 2008).

Within the southwestern United States we know of three Indian ricegrass ecotypes that have been developed and released; 'Starlake' from McKinley county, New Mexico,
Table 6. Seeds zone areas and number of source collection locations within each seed zone for Indian ricegrass across the southwestern United States.

\begin{tabular}{lccr}
\hline Seed zone & \multicolumn{1}{c}{$\begin{array}{c}\text { Area } \\
\left(\mathrm{km}^{2}\right)\end{array}$} & $\begin{array}{c}\text { \% of } \\
\text { mapped area }\end{array}$ & No. $^{2}$ \\
\hline H1H2H3 & 32845.9 & 3.03 & 3 \\
H1H2L3 & 24808.1 & 2.29 & 1 \\
H1L2H3 & 119066.9 & 11.0 & 3 \\
H1L2L3 & 15440.8 & 1.42 & 1 \\
M1H2H3 & 127031.1 & 11.7 & 31 \\
M1H2L3 & 68811.0 & 6.35 & 12 \\
M1L2H3 & 324657.1 & 29.9 & 35 \\
M1L2L3 & 101311.2 & 9.34 & 8 \\
L1H2H3 & 48709.5 & 4.49 & 3 \\
L1H2L3 & 15630.5 & 1.44 & 1 \\
L1L2H3 & 174859.6 & 16.1 & 7 \\
L1L2L3 & 31304.6 & 2.89 & 1 \\
Totals & 1084476.2 & 100.0 & 106 \\
\hline
\end{tabular}

${ }^{1} \mathrm{H} 1, \mathrm{M} 1$, and L1 refer to high, middle and low ranges of cancorr extract 1 scores; $\mathrm{H} 2$ and $\mathrm{L} 2$, and $\mathrm{H} 3$ and L3, refer to high and low ranges of cancorr extracts 2 and 3, respectively.

${ }^{2}$ Number of collections falling within a given seed zone.

'Paloma' from near Florence, Colorado (USDA-NRCS 2000), and 'Whiteriver' from near Rangely, Colorado (Jones et al. 2010). As nearly as could be determined, they originated from within seed zones $\mathrm{M} 1 \mathrm{H} 2 \mathrm{H} 3$ and MIH2L3, which represent less than $20 \%$ of the mapped area (Table 6). The largest seed zone, M1L2H3, representing major portions of the Central Basin and Range, the Wyoming Basin, and eastern Colorado, is not represented by released germplasm. Nor are significant portions of the Colorado and Arizona/New Mexico plateaus. Moreover, four of the seed zones currently have only one available collection (Table 6), emphasizing the need for new collections, especially in those areas.

This need could be approached within seed zones through expansion of the traditional collection and selection of single ecotypes or their variants with the goal of enhancing agronomic characteristics, such as reduced dormancy (USDA-NRCS 2000; Jones et al. 2010). Alternatively, collections of unselected populations within seed zones could be grown, released, and replanted within each seed zone. Although the former allows more efficient seed production, the latter encourages restoration based on more regionally adapted, diverse populations over the landscape, allowing greater scope for adaptation to changing conditions and climates.

\section{IMPLICATIONS}

Disturbances from abiotic and biotic stress in the southwestern United States have heightened the need for restoration on rangelands. An additional concern is the potential loss of genetic diversity among populations associated with habitat degradation and climate change. Indian ricegrass is a native, widely distributed, highly desirable species in desert ecosystems for wildlife and grazing. Multilinear regression models linking genetic variation and climate were used with GIS, to map seed zones for Indian ricegrass across the southwestern United 
States. The seed zones will provide guidance for choosing germplasm for current and future restoration. Use of these guidelines will also broaden the range of genetic diversity utilized across the landscape and promote the capacity for future adaptation of Indian ricegrass to climate.

\section{ACKNOWLEDGMENTS}

The authors thank Melissa Scholten for her technical support and data collection.

\section{LITERATURE CITED}

Bischoff, A., T. Steinger, and H. Müller-Schärer. 2010. The importance of plant provenance and genotypic diversity of seed material used for ecological restoration. Restoration Ecology 18:338-348.

Bleak, A. T., N. C. Frischknecht, A. P. Plummer, and R. E. Eckert, JR. 1965. Problems in artificial and natural revegetation of the arid shadscale vegetation zone of Utah and Nevada. Journal of Range Management 18:59-65.

Bohmont, B. L., and R. Lang. 1957. Some variations in morphological characteristics and palatability among geographic strains of Indian ricegrass. Journal of Range Management 10:127-131.

Daly, C., M. Halbleib, J. I. Smith, W. P. Gibson, M. D. Doggett, G. H. Taylor, J. Curtis, AND P. PAsteris. 2008. Physiographically sensitive mapping of climatologically temperature and precipitation across the conterminous United States. International Journal of Climatology 28:2031-2064. doi:10.1002/joc.1688

Draper, N. R., And H. Smith. 1998. Applied regression analysis. 3rd ed. New York, NY, USA: John Wiley \& Sons, $706 \mathrm{p}$.

EndLeR, J. A. 1986. Natural selection in the wild. Princeton, NY, USA: Princeton University Press. 336 p.

Horning, M. E., T. R. McGovern, D. C. Darris, N. L. Mandel, and Randy Johnson. 2008 Genecology of Holodiscus discolor (Rosaceae) in the Pacific Northwest, USA. Restoration Ecology 18:235-243.

Hufford, K. M., and S. J. Mazer. 2003. Plant ecotypes: genetic differentiation in the age of ecological restoration. Trends in Ecology and Evolution 18:147-155.

JefFries, D. L., AND J. M. KLopateK. 1987. Effects of grazing on the vegetation of the blackbrush association. Journal of Range Management 40:390-392.

JonEs, T. A. 1990. A viewpoint on Indian ricegrass research: its present status and future prospects. Journal of Range Management 43:416-420.
Jones, T. A., And T. A. Monaco. 2009. A role for assisted evolution in designing native plant materials for domesticated landscapes. Frontiers in Ecology and Environment 7:541-547.

Jones, T. A., AND D. C. Nielson. 1989. Self-compatibility in 'Paloma' Indian ricegrass. Journal of Range Management 42:187-190.

Jones, T. A., AND D. C. NieLson. 1992. Germination of prechilled mechanically scarified and unscarified Indian ricegrass seed. Journal of Range Management 45:175179.

Jones, T. A., S. R. Winslow, S. D. ParR, and K. L. Memmott. 2010. Notice of release of White River germplasm Indian ricegrass. Native Plants Journal 11:133-136.

Johnson, R., L. Stritch, P. Olwell, S. Lambert, M. E. Horning, and R. Cronn. 2010. What are the best seed sources for ecosystem restoration on BLM and USFS lands? Native Plants Journal 11:117-130.

Johnson, R. C., V. J. Erickson, N. L. Mandel, J. B. St Clair, and K. W. Vance-Borland. 2010. Mapping genetic variation and seed zones for Bromus carinatus in the Blue Mountains of eastern Oregon, U.S.A. Botany 88:725-736.

Jump, A. S., R. Marchant, and J. Penúelas. 2008. Environmental change and the option value of genetic diversity. Trends in Plant Science 14:51-58.

KaweCKI, T. J., AND D. EBert. 2004. Conceptual issues in local adaptation. Ecological Letters 7:1225-1241.

LeIMU, R., AND M. FISCHER. 2008. A meta-analysis of local adaptation in plants. PLoS ONE 3:e4010. doi:10.1371/journal.pone.0004010

Mallows, C. L. 1973. Some comments on Cp. Technometrics 15:661-675.

Manly, B. F. J. 1986. Multivariate statistical methods: a primer. New York, NY, USA: Chapman and Hall. $159 \mathrm{p}$.

McAdoo, J. K., C. C. Evans, B. A. Roundy, J. A. Young, and R. A. Evans. 1983. Influence of heteromyid rodents on Oryzopsis hymenoides germination. Journal of Range Management 36:61-64.

OMernik, J. M. 1987. Ecoregions of the conterminous United States. Annals of the Association of American Geographers 77:118-125.

Pearson, L. C. 1979. Effects of temperature and moisture on phenology and productivity of Indian ricegrass. Journal of Range Management 32:127-134.

RehfeLdT, G. E. 1986. Adaptation of Pinus ponderosa from the intermountain regions. 1. Snake and Salmon river basins. Forest Science 32:79-92.

RICE, K. J., AND E. E. Knapp. 2008. Effects of competition and life history stage on the expression of local adaptation in two native bunchgrasses. Restoration Ecology 16:12-23.

St Clair, J. B., N. L. Mandel, and K. W. Vance-Borland. 2005. Genecology of Douglas fir in western Oregon and Washington. Annals of Botany 96:1199-1214. doi:10. 1093/aob/mci278

USDA-NRCS. 2000. The PLANTS database. Version: 000417. Baton Rouge, LA, USA: National Plant Data Center. Available at: http://plants.usda.gov. 